\title{
Analysis of the Learning Implementation Plan for the Big Ball Game Material Oriented High Order Thinking Skills (HOTS) in State Junior High Schools Throughout the District Bantul
}

\author{
Suhadi Suhadi ${ }^{1, *}$ Sri Mawarti ${ }^{1,}$ Nurhadi Santoso ${ }^{1,}$ Riky Dwihandaka $^{1}$ \\ ${ }^{I}$ Faculty of Sports Science, Universitas Negeri Yogyakarta, Yogyakarta, Indonesia \\ "Corresponding author.Email: suhadi_fik@uny.ac.id
}

\begin{abstract}
The Learning Implementation Plan (RPP) is the main key in learning. This study aims to analyze the lesson plans for large ball games oriented towards High Order Thinking Skills (HOTS) in State Junior High Schools throughout Bantul Regency, Yogyakarta Special Region. The design in this research is descriptive quantitative, with document analysis method. The document analysis covers 22 lesson plans from 22 schools. The sampling technique used purposive sampling. The main analysis includes the analysis of the big ball game lesson plans covering eight components or indicators, namely: formulation of indicators, learning objectives, learning methods, learning activities, learning assessments, learning media, learning materials, and learning resources using document analysis guidelines with descriptors ranging from 1 (not suitable) to 4 (very suitable). The data analysis technique uses quantitative descriptive analysis and is presented in the form of percentages. The results showed that the overall RPP analysis of the big ball game was HOTS-oriented with the highest percentage in the appropriate category. The learning resource component is the lesson plan component which has the lowest average of 3.05. The learning activity component is the lesson plan component which has the highest average of 4.00. It can be concluded that learning resources need to get the main attention to be improved in order to realize HOTS learning. Therefore, future research should consider the type of game, level of education, region or area, and conditions (COVID-19 Pandemic).
\end{abstract}

Keywords: Analysis, Big Ball Game Material, HOTS

\section{INTRODUCTION}

Undang-Undang Nomor 20 Tahun 2003 tentang Sistem Pendidikan Nasional Bab I Pasal 1 (Ayat 1) explains that education is a conscious and planned effort to create a learning atmosphere and learning process so that students actively develop their potential to have religious spiritual strength, personality self-control intelligence, noble character, and skills needed by himself, society, nation and state. Furthermore, Article 3 states that National Education functions to develop and shape the character and civilization of a dignified nation in the context of educating the nation's life, aiming at developing the potential of students to become human beings who believe and fear God Almighty, have noble character, are healthy, knowledgeable, capable, creative, independent, and become a democratic and responsible citizen.
Education as an educational activity or teaching and learning activity, whose essence lies in learning, and the essence of learning lies in thinking (Sanusi, 2013: 23). Education is an effort to teach students to think. Learners must emphasize thinking skills. Students must be directed to be able to think critically, think high-level and be independent in learning activities. Therefore, education has a close relationship with learning.

Learning is a systematic and systemic process or activity that is interactive and communicative between educators (teachers) and students, learning resources, and the environment to create a condition that allows student learning actions to occur. Physical Education, Sports and Health (PJOK) is one of the subjects taught in Junior High Schools. The scope of subject matter for Physical Education, Sports and Health for SMP/MTs consists of: Games and Sports Activities, Fitness 
Activities, Gymnastics and Rhythmic Movement Activities, Water Activities, and Health. PJOK learning in junior high schools in general has been at the stage of specialized or specific movements that have matured, and are ready to be applied to functional skills of daily life, various competitive games and sports, and recreational activities in free time. PJOK learning in junior high school should have reached the cognitive level. The age of junior high school students is the age of transition between early adolescence and late adolescence. Johnson \& Johnson (2009: 63) states that based on Piaget's opinion, children aged 15-18 years are included in the most complex stages of cognitive development. Children are able to think hypothetically well, think logically with descriptions, good verbal skills in logical thinking. Therefore, the importance of an appropriate method for learning at the junior high school age which has the hope that built with the 2013 curriculum, junior high school students are able to develop themselves, especially in terms of analytical skills. Although it does not rule out the hierarchy below it. One method that fits the description above is HOTS (Higher Order Thinking Skills). Higher Order Thinking Skills (HOTS) is the output of learning outcomes, one of the things that causes low learning outcomes is teachers teaching with a one-way (conventional) approach. In one-way learning, students are not given the opportunity to use their thinking further, so that when faced with theories and practices that require higher-order thinking skills, such as deep analysis or reasoning, students will find it difficult. Based on this assumption, it is necessary for teachers to use learning that can lead students to higher order thinking skills (Marjan et al, 2014: 3).

The Learning Implementation Plan (RPP) prepared by the PJOK teacher must be in accordance with the curriculum used, namely the 2013 curriculum. The 2013 curriculum is a competency-based curriculum in which the 2013 curriculum uses a scientific approach or commonly called the scientific approach, namely observing, asking, trying, reasoning. and communicate. The purpose of using the scientific approach model based on the 2013 Curriculum Diktat Module is intended to provide understanding to students in recognizing, understanding various materials using a scientific approach, that information can come from anywhere, anytime, not depending on direct information from the teacher. Therefore, the learning conditions that are expected to be created are directed at encouraging students to find out from various sources of observation, not being told (Majid \& Rochman, 2014: 70). Based on observations in several junior high schools in Bantul Regency, all of them already have an educational background, experience in teaching for 5 to 25 years. The results of interviews conducted showed that several PJOK teachers attended workshops on the preparation of lesson plans, teachers also always made and prepared lesson plans at the beginning of the semester. The PJOK teacher at the State Junior High School in Bantul Regency uses the RPP resulting from the MGMP, but there is also one teacher who prepares some of the RPP he made himself. Another problem, related to the implementation of the 2013 curriculum in the field, there are still some obstacles in its implementation, some PJOK teachers still do not understand the 2013 curriculum. In practice, teachers are still dominant in teaching (teacher center). This is in stark contrast to the modern era of $21 \mathrm{st}$ century skills, where students are more active in learning (student center). Until now there has not been much research related to the analysis of HOTS-oriented materials, especially PJOK subjects. Research related to HOTS was conducted by Arifah Ari Arsiwi, the main analysis focused on learning materials for the basketball game. For this reason, the purpose of writing this article is to provide a description of the results of the analysis of the HOTS-oriented big ball game learning material. The analysis carried out was developed more broadly, not only on one form of play, but also covered all forms of big ball games. The description includes the components of the lesson plans, totaling 8 components, namely: 1) Formulation of indicators, 2) Learning objectives, 3) Learning methods, 4) Learning activities, 5) Learning assessments, 6) Learning media, 7) Learning materials, and 8) Learning resources. Therefore, this study aims to analyze the RPP for the HOTS-oriented big ball game at State Junior High Schools throughout Bantul Regency, Yogyakarta Special Region.

\section{METHOD}

\subsection{Participants}

In this study, document analysis covered 22 lesson plans from 22 schools.

\subsection{Procedure}

The main analysis includes the analysis of the big ball game lesson plans covering eight components or indicators, namely: formulation of indicators, learning objectives, learning methods, learning activities, learning assessments, learning media, learning materials, and learning resources using document analysis guidelines with descriptors ranging from 1 (not suitable) to 4 (very suitable).

\subsection{Data Collection}

The instrument in this study was a document analysis sheet. The instrument used in this study is an assessment rubric. The grading scale in the rubric uses a modified Likert scale: 
Table 1. Assessment Score

\begin{tabular}{|c|c|}
\hline Score & Description \\
\hline 1 & Not Suitable \\
\hline 2 & Not Appropriate \\
\hline 3 & Appropriate \\
\hline 4 & Very Suitable \\
\hline
\end{tabular}

\subsection{Data Analysis}

Descriptive analysis of the percentage using the formula (Sudijono, 2009: 40):

$P=\frac{f}{N} \times 100 \%$

Description:

$$
\begin{aligned}
& \mathrm{P}=\text { Percentage sought } \\
& \mathrm{f}=\text { Frequency } \\
& \mathrm{N}=\text { Number of respondents }
\end{aligned}
$$

\section{RESULT}

The results of the RPP analysis of learning materials for big ball games in State Junior High Schools throughout Bantul Regency as a whole are as follows:

Table 2. Descriptive Statistics of Overall Analysis Results

\begin{tabular}{|c|c|c|c|c|}
\hline & Mean & $\begin{array}{c}\text { Std. } \\
\text { Deviation }\end{array}$ & Minimum & Maximum \\
\hline Overall & 30.00 & 1.8516 & 23 & 31 \\
\hline
\end{tabular}

The overall descriptive analysis shows that the lesson plans for learning the big ball game are included in the appropriate category. If depicted in the form of a histogram:

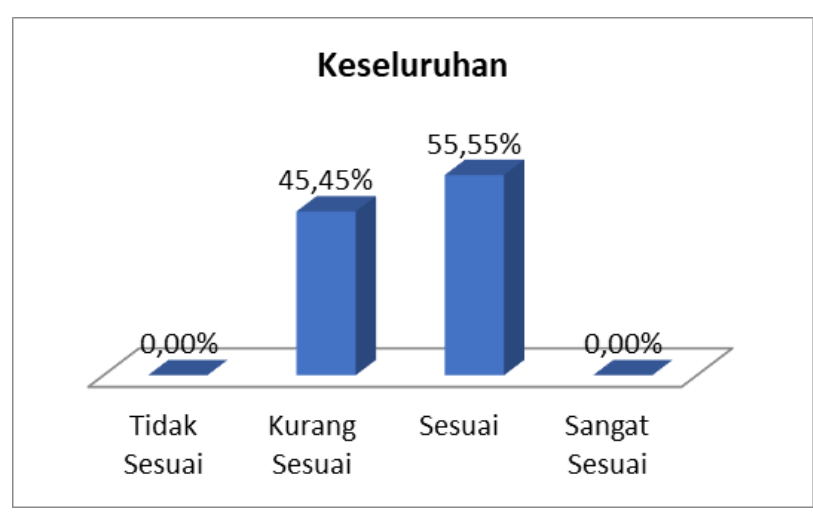

Figure 1 Overall Analysis Histogram
The results of the analysis based on the components of the Learning Implementation Plan can be seen in table 3 .

Table 3. Descriptive Statistics of RPP Component Analysis Results (n 22)

\begin{tabular}{|l|c|c|c|c|}
\hline \multicolumn{1}{|c|}{ RPP Component } & Mean & $\begin{array}{c}\text { Std. } \\
\text { Deviation }\end{array}$ & Min & Max \\
\hline $\begin{array}{l}\text { 1. Formulation of } \\
\text { indicators }\end{array}$ & 3,95 & 0,213 & 3 & 4 \\
\hline 2. Learning objectives & 3,86 & 0,351 & 3 & 4 \\
\hline 3. Learning methods & 3,82 & 0,395 & 3 & 4 \\
\hline 4. Learning activities & 4,00 & 0,000 & 4 & 4 \\
\hline $\begin{array}{l}\text { 5. Learning } \\
\text { assessments }\end{array}$ & 3,82 & 0,501 & 2 & 4 \\
\hline 6. Learning media & 3,77 & 0,528 & 2 & 4 \\
\hline 7. Learning materials & 3,73 & 0,550 & 2 & 4 \\
\hline 8. Learning resources & 3,05 & 0,375 & 2 & 4 \\
\hline
\end{tabular}

Descriptive statistical analysis shows that the lowest average is in the learning resource component, the highest average is in the learning activity component. Minimum scores on four components, namely: learning assessment, learning media, learning materials, and learning resources.

\section{DISCUSSION}

The results showed that the overall RPP analysis of the big ball game material was included in the appropriate category, this result is in line with the research of Galih Kumara \& Ahmad Rithaudin (2019) which in their study of the analysis of PJOK teachers' RPP on learning that included HOTS in State Junior High Schools throughout the East Sleman Region. are in the good category of $93.75 \%$ and sufficient at $6.25 \%$. Even though it was carried out in different areas, it turned out that the two studies had similar results. These results also strengthen the research conducted by Veni Imawati (2017) with a study of the evaluation of the first semester PJOK lesson plans at SMPN 6 Malang, that the level of conformity of the lesson plans was included in the very good category.

The results of the study based on the RPP component showed that the learning resources had the lowest average. Ariyana, Pudjiastuti, Bestary, \& Zamroni (2018) state that learning materials and resources are all materials and resources that can be used by students in learning, either separately or in combination that can help make it easier for students to achieve certain competencies. Learning materials and resources can be in the form of books, data, people, environment, nature and so on.

Learning resources must be written clearly and definitely in the lesson plans. Most of the lesson plans 
made by teachers at SMP Bantul Regency do not include clear and varied learning resources. While the components of learning activities are in accordance with what they should be, this is proven by the highest average value. Ariyana, Pudjiastuti, Bestary, \& Zamroni (2018) stated that learning activities aim to develop students' attitudes, knowledge, and skills and their application in various situations, both at school, family, and community. The process takes place through faceto-face activities in class, structured activities, and independent activities. Face-to-face activities are activities that are mapped out in meetings. Each meeting contains preliminary activities, core activities and closing activities.

\section{CONCLUSION}

Analysis of the overall big ball game learning implementation plan with the highest percentage in the appropriate category. The learning resource component is the lesson plan component which has the lowest average. The learning activity component is the lesson plan component that has the highest average. Therefore, learning resources need to be the main concern to be improved in order to realize HOTS-oriented learning. Future research should consider the type of game, level of education, region or area, and conditions (COVID-19 Pandemic).

\section{ACKNOWLEDGMENT}

This research was funded by the 2020 UNY DIPA FUND. Therefore, on this occasion the authors would like to thank LPPM and FIK UNY for all the facilities so that the research can run smoothly and hopefully the results of this research can be useful.

\section{REFERENCES}

[1] Ariyana, Y., Pudjiastuti, A., Bestary, R. \& Zamroni. (2018). Buku Pegangan Pembelajaran Berorientasi pada Keterampilan Berpikir Tingkat Tinggi. Direktorat Jenderal Guru dan Tenaga Kependidikan Kementerian Pendidikan dan Kebudayaan.

[2] Galih Kumara \& Ahmad Rithaudin. (2019). Analisis Rencana Pelaksanaan Pembelajaran Kelas VII Mapel PJOK Ditinjau dari Higher Order Thinking Skills (HOTS) di SMP Negeri seWilayah Sleman Timur. Skripsi. Yogyakarta: FIK UNY.

[3] Johnson, D. W., \& Johnson, R. T. (2009). An educational psychology success story: Social interdependence theory and cooperative learning. Educational Researcher, 38(5), 365- 379.
[4] Majid, A., \& Rochman, C. (2014). Pendekatan ilmiah dalam implementasi kurikulum 2013. Bandung: PT Remaja Rosdakarya.

[5] Marjan. (2014). Pengaruh pembelajaran pendekatan saintifik terhadap hasil belajar biologi dan keterampilan proses sains siswa MA Mu'allimat NW Pancor Selong Kabupaten Lombok Timur Nusa Tenggara Barat. Jurnal Universitas Pendidikan Ganesha, Volume 4.

[6] Sanusi, A., (2013). Kepemimpinan pendidikan: strategi pembaruan, semangat pengabdian, manajemen modern. Bandung: Nuansa Cendekia.

[7] Sudijono, A. (2009). Pengantar statistik pendidikan. Jakarta: Rajawali Pers.

[8] Undang-Undang No 20 Tahun 2003 tentang sistem Pendidikan Nasional, Bab I Ketentuan Umum Pasal 1 Ayat 20.

[9] Veni Imawati. (2017). Evaluasi Rencana Pelaksanaan Pembelajaran Pendidikan Jasmani Olahraga dan Kesehatan Semester I di SMPN 6 Malang. Skripsi. Malang: FIK UM. 